\title{
DOI 10.26886/2520-7474.6(26)2017.2
}

UDC: 94

\section{TRADE OF ANCIENT CARTHAGE}

\section{Doctor of History, W. O. Orehowskyi}

Chernivtsi trade and economic institute of the Kyiv national trade and economic university, Ukraine, Chernivtsi

Trade of Ancient Carthage is described in theses - one of the mightiest states of Western Mediterranean in I of thousand B. C. An author marks that trade activity (especially intermediary) was the nearly most main source of prosperity of local population. It is marked that to take new markets and could master adherent territories of Carthaginians, based by high level of own shipbuilding.

Keywords: Carthage, seagoing, trade, Mediterranean, shipbuilding, colonization.

доктор історичних наук, Ореховський В. О. Торгівля стародавнього Карфрагену / Чернівецький торговельно-економічний інститут Київського національного торговельно-економічного університету, Україна, м. Чернівці

У тезах охарактеризовано торгівлю Стародавнього Карфрагену - однієї із наймогутніших держав Західного Середземномор'я I тис до н.е. Автор відзначає, що торговельна діяльність (особливо посередницька) була чи не найголовнішим джерелом процвітання місцевого населення. Зазначається, що захоплювати нові ринки та освоювати прилеглі території карфрагеняни могли, спираючись на високий рівень власного суднобудування.

Ключові слова: Карфраген, мореплавство, торгівля, Середземне море, суднобудування, колонізація. 
Доктор исторических наук, Ореховский В. О. Торговля древнего Карфрагена / Черновицкий торгово-экономический институт Киевского национального торгово-экономического университета, Украина, е. Черновцы

В тезисах охарактеризована торговля Древнего Карфагена одного из самых могущественных государств Западного Средиземноморья I тыс. до н.э. Автор отмечает, что торговая деятельность (особенно посредническая) была едва ли не главнейшим источником процветания местного населения. Отмечается, что захватывать новые рынки и освачвать прилегающие территории карфрагеняне могли, опираясь на высокий уровень собственного судостроения.

Ключевые слова: Карфраген, мореплавание, торговля, Средиземное море, судостроение, колонизация.

Середземне море 3 найдавніших часів відігравало роль своєрідного «мосту» у взаємодії різних держав, народів та культур. Воно стало також і «колискою» ряду людських цивілізацій.

Особливе місце серед них займає фрінікійська, представники якої стали першими «справжніми купцями», «володарями античних морів». Невід'ємною від торгівлі була і активна колонізаційна політика останніх.

До «зони інтересів» фрінікійців потрапило і Західне Середземномор'я. На шляху сюди була створена низка поселень, що могли служити базами для кораблів, а також опорними пунктами при військових конфрліктах. Найважливішим з них став Карфаген, держава, що пережила саму Фінікію і декілька століть була могутнім суперником Римської республіки. 
Одним із джерел могутності та багатства Карфагенської держави була активна торговельна діяльність ії населення. За словами відомого російського дослідника Ю.Б. Циркіна, Карфаген «... з самого початку розвивався в першу чергу як центр посередницької торгівлі. I тільки значно пізніше в його економіці значну роль почало відігравати сільське господарство» [7, с.70].

Карфагенські купці «освоїли» величезну територію - від ПівнічноЗахідної Африки до Причорномор'я та від Іспанії до Єгипту.

Радянський сходознавець І.Ш.Шифман так красномовно описував все багатство торговельної «палітри» Карфагену: «Не було такого товару, який не можна було б побачити на ринку Карфрагена, грецьке та італійське вино, етруські вази, золото та срібло буквально звідусіль, металеві прикраси для жінок і зброю для чоловіків, дороге взуття, мавп і, звичайно, чорних і білих рабів. Не було такої країни, куди б не плавали пунійські моряки зі своїми товарами, звідки не приходили б до Карфагену торгові кораблі. Не було таких виробів від дорогоцінних бронзових світильників до глиняних глеків, які не виготовляли б численні пунійські ремісники, і вільні і залежні від багатих торговців» [10, с.58].

Карфагенське купецтво активно займалось і посередницькою торгівлею. Так, олію, кераміку, скло, фаянс та вино карфагеняни перевозили на західне узбережжя Африки, а звідти вивозили шкури та слонову кістку. Експортували вони також і африканські дорогоцінні камені. Об'єктом посередницької торгівлі виступали і метали з Іспанії $[7$, c.79].

Значне місце у системі торговельних відносин Карфагенської держави відігравало рабство. Рабів захоплювали в результаті воєн, їх постачальниками були пірати та племінні князі. Нерідко карфагеняни вимінювали рабів однієї категорії на іншу. Так, на 
Балеарських островах високо цінувалися жінки і за кожну жінку карфагенські купці отримували 4 або 5 чоловіків [4, с.43-44] .

Карфрагенська держава приділяла значну увагу торгівлі. Свідченням цього стали ряд торговельних угод, що були укладені 3 етрусками та римлянами.

Так, за угодою (509 р. до н.е.) проводилось своєрідне розмежування карфагенської та римської «сфер впливу». Давньогрецький історик Полібій наводить основні положення цього документу: «...римлянам і союзникам римлян забороняється плисти далі за Прекрасний мис, хіба до того вони будуть вимушені бурею або ворогами. Якщо хто-небудь занесений буде проти бажання, йому не дозволяється ні купувати що-небудь, ні брати крім того, що вимагається для лагодження судна або для жертви. ... Ті, які прийшли у торгових справах не можуть вчинити ніякої угоди інакше, як за посередництва глашатая або писаря. За усе те, що у присутності цих свідків не було би продано в Лівії або Сардинії, ручається перед продавцем держава. Якщо хтось із римлян з'явиться до підвладної карфрагенянам Сицилії, то в усьому римляни користуватимуться однаковими правами з карфагенянами. 3 іншого боку, карфагенянам забороняється кривдити... латинський народ, підлеглий римлянам. Якщо який народ i не підлеглий римлянам, карфагенянам забороняється тривожити міста їх; а якщо яке місто вони візьмуть, то зобов'язуються повернути його в цілості римлянам» [5, с.266-267].

Вести торгівлю на такому величезному ринку допомагали досконалі кораблі. Тут карфагеняни були спадкоємцями і продовжувачами фрінікійських суднобудівників. Їх торговельні кораблі булі досить широкими і тому, на противагу вузьким і довгим військовим суднам, називалися «круглими». Рухалися вони за допомогою вітрил, але, у разі необхідності, застосовувалися і весла. 
Кораблі виготовлялися з кедру, матеріалом же для весел був дуб [11, с. 107]. Основу судна складала подовжня балка - кіль, на яку нарощувалися шпангоути і обшивались дошками. Для запобігання протіканню води щілини між останніми ретельно проконопачувались $[10$, c.18]. Для керування кораблем використовували два кормових весла. Впоратись з ними могла одна людина. Палубних надбудов на кораблі не було. Всі приміщення для моряків та пасажирів, а також трюм для вантажу знаходились під палубою [1, с.100].

Це був не єдиний тип морського корабля. Існували судна, що призначалися для плавання на далекі відстані. Вони були достатньо великими, мали спеціальні приміщення для відпочинку екіпажу та пасажирів. Такий корабель мав закруглений корпус, його корма була піднята у вигляді лебединої шиї, передня ж частина завершувалася кабіною спостерігача. Судно оснащувалось не одним, а двома вітрилами ( у центрі та носовій кінцівці) [8, с.7]. Пізніше з'явилися менші за розмірами але більш швидкісні кораблі. Судна цього типу мали носову прикрасу у вигляді кінської голови і тому часто називалися «конями» $[11$, с.107].

Темпи будівництва часом вражали. Так, за словами давньогрецького географра Страбона, на карфагенських верфях під час III Пунічної війни, в умовах облоги міста римлянами, було побудовано за два місяці 120 палубних військових кораблів [6, с. 766] .

У пошуках нових ринків карфагеняни організовували масштабні морські експедиції. Приблизно між 505 і 450 рр. до нашої ери сенат Карфагену відправляє ескадру на чолі із мореплавцем Ганноном. Повідомлення про цей похід збереглося до наших днів у вигляді своєрідного документу - так званого Перипла Ганнона, що є звітом про плавання загону карфагенян за Гераклові Стовпи (Гібралтарська протока) [9, с.168]. У Периплі вказувалось: «Ухвалили карфагеняни, 
щоб Ганнон плив за Гераклові Стовпи і засновував міста лівіофінікіян. I він відплив, ведучи шістдесят пентеконтер (судно з п'ятдесятьма веслами), і безліч чоловіків і жінок, числом в тридцять тисяч, і везучи хліб та інші припаси» [9, с.168] .

Кораблі Ганнона пройшли Гібралтарську протоку і попрямували на південь, уздовж узбережжя Західної Африки. Кінцевою точкою експедиції стала територія сучасної Ліберії [3, с.43].

Подорожуючи уздовж західного берега Африки, Ганнон наносив на карту рельєф місцевості, берегову лінію, давав назви мисам і затокам. Нестача харчів і втома змусили повернути назад до Карфрагену. Але експедиція пройшла більше 2 тис. км. ІІї результатом було заснування декількох десятків колоній, тисячі кілометрів освоєних територій, а головне - детальна карта значної частини західного узбережжя Африки [2, с.24-25].

Отже, карфагеняни створили одну з найбільш квітучих цивілізацій Західного Середземномор'я. Переважно торгівельний характер останньої зумовив активний пошук нових ринків збуту та колонізацію відкритих земель. I тут саме вихідці з Карфагену довго панували на водних просторах. Вони внесли неоцінений вклад у розвиток торгівлі та освоєння морських шляхів Старого Світу.

\section{תimepamypa:}

1. Волков А. В. Загадки Финикии / Волков Александр Викторович. М.: Вече, 2004. - 320 с. - («Таинственные места Земли»).

2. История туризма: Сборник / Составители Макаренко С. Н., Саак А. Э.- Таганрог: Изд-во ТРТУ, 2003. - 94 с. 
3. История туризма: учебник / коллектив авторов; отв. ред. и сост. Ю. С. Путрик. - М.: Федеральное агентство по туризму, 2014. $256 \mathrm{c}$.

4. Машкин Н. А. Карфрагенская держава до пунических войн / H. A. Машкин // Вестник древней истории - 1948. - № 4(26). - С.35-54.

5. Полибий. Всеобщая история / Полибий [пер. Ф. Г. Мищенко]. - М.: Типографрия Е. Г. Потапова, 1890.- T. I. - CCXLIII +680+VIII.

6. Страбон. География: пер. с греческого Г.А. Стратановского / Страбон. - М.: Наука, 1964. - 944 с.

7. Циркин Ю. Б. Карфаген и его культура/ Ю. Б. Циркин. - М.: Главная редакция восточной литературы издательства «Наука», 1986. - 287 с. с ил. («Культура народов Востока»).

8. Циркин Ю. Б. Мифы Финикии и Угарита / Ю. Б. Циркин. - М.: ООО «Издательство АСТ»: ООО «Издательство Астрель», 2003. - 478, [2] с.: ил. - (Мифы народов мира).

9. Шифрман И. Ш. Карфраген / Илья Шолеймович Шифрман.- СПб.: Издво СПбГУ, 2006. - 518 c.

10. Шифмман И. Ш. Финикийские мореходы / Илья Шолеймович Шифман. - М.: Наука, ГРВЛ, 1965. - 84 с.: ил. - Серия «По следам исчезнувших культур Востока».

11. Штенцель А. История войны на море в ее важнейших проявлених с точки зрения морской тактики / Альфред Штенцель. - Ч.І. Петроград: Типография Морского Министерства, 1916. - 332 с.

\section{References:}

1. Volkov A. V. Zahadky Fynykyy / Volkov Aleksandr Vyktorovych. - M.: Veche, 2004. - 320 s. - («Taynstvennye mesta Zemly»).

2. Ystoryya turyzma: Sbornyk / Sostavytely Makarenko S. N., Saak A. E.Tahanroh: Yzd-vo TRTU, 2003. - 94 s. 
3. Ystoryya turyzma: uchebnyk / kollektyv avtorov; otv. red. y sost. Yu.S. Putryk. - M.: Federal'noe ahentstvo po turyzmu, 2014. - 256 s.

4. Mashkyn N. A. Karfahenskaya derzhava do punycheskykh voyn / N. A. Mashkyn // Vestnyk drevney ystoryy - 1948. - № 4(26). - S.35-54.

5. Polybyy. Vseobshchaya ystoryya / Polybyy [per. F. H. Myshchenko]. M.: Typohrafyya E. H. Potapova, 1890.- T. I. - CCXLIII +680+VIII.

6. Strabon. Heohrafyya: per. s hrecheskoho H. A. Stratanovskoho / Strabon. - M.: Nauka, 1964. - 944 s.

7. Tsyrkyn Yu. B. Karfahen y eho kul'tura/Yu. B. Tsyrkyn. - M.: Hlavnaya redaktsyya vostochnoy lyteratury yzdatel'stva "Nauka», 1986. - 287 s. s yl. («Kul'tura narodov Vostoka»).

8. Tsyrkyn Yu. B. Myfy Fynykyy y Uharyta / Yu. B. Tsyrkyn. - M.: OOO «Yzdatel'stvo AST»: OOO «Yzdatel'stvo Astrel'», 2003. - 478, [2] s.: yl. - (Myfy narodov myra).

9. Shyfman Y. Sh. Karfahen / Yl'ya Sholeymovych Shyfman.- SPb.: Yzdvo SPbHU, 2006. - $518 \mathrm{~s}$.

10. Shyfman Y.Sh. Fynykyyskye morekhody / Yl'ya Sholeymovych Shyfman. - M.: Nauka, HRVL, 1965. - 84 s.: yl. - Seryya «Po sledam yscheznuvshykh kul'tur Vostoka».

11. Shtentsel' A. Ystoryya voyny na more $v$ ee vazhneyshykh proyavlenykh s tochky zrenyya morskoy taktyky / Al'fred Shtentsel'. - Ch.I. - Petrohrad: Typohrafyya Morskoho Mynysterstva, 1916. - 332 s. 